\title{
In vitro study on the antitumor activity of Tanacetum vulgare L. extracts
}

\author{
A.M. Vasileva ${ }^{1 *}$, I. A. Iliev², V. S. Lozanov ${ }^{1}$, M. B. Dimitrova ${ }^{2}$, V. I. Mitev¹, I. P. Ivanov ${ }^{1}$ \\ ${ }^{1}$ Department of Medical Chemistry and Biochemistry, Medical University of Sofia, 2, Zdrave Str., Sofia 1431, Bulgaria \\ ${ }^{2}$ Institute of Experimental Morphology, Pathology and Anthropology with Museum, Bulgarian Academy of Sciences, \\ Acad. G. Bonchev Str., Bl. 25, 1113 Sofia
}

Received December 20, 2018; Revised January 24, 2019

\begin{abstract}
The major nonvolatile compounds derived from extracts and fractions from Tanacetum vulgare L. flowers were determined by LC-HRMS. Major compounds in the crude extract were determined to be: six hydroxycinnamoyl quinic acids with 4,5-dicaffeoylquinic acid and twelve flavonoids and their derivatives, six of which were in the form of flavonoid-O-glucuronides. Generally, the major flavonoid aglycone in tansy was luteolin. Extracts and fractions were tested under in vitro conditions in nine cell lines - one control non-tumorogenic and eight tumor lines, whereby antitumor activity was observed after 72 hours of incubation with the aforementioned substances as determined by an MTT assay. The obtained results show the highest selectivity index for the ethyl acetate extract from Flores Tanaceti (EAFT) and for the ethyl acetate fraction of the crude extract (EACE). EAFT extract was found to exert the highest antitumor effect, followed by EACE. From the above results it becomes evident that ethyl acetate extracts of T. vulgare contain substances with high selective activity against tumor cells.
\end{abstract}

Key words: Tanacetum vulgare L.; phenolic compounds; cancer cell line; cell viability; antitumor activity

\section{INTRODUCTION}

Globally, the incidence of oncological diseases increases compared to other life-threatening pathologies. Therefore, there is a high demand for high-efficiency low-toxicity therapeutic agents with anti-tumor activity. Natural products are a good alternative to commonly used cytotoxic agents because of their good biological tolerance and high metabolic breakdown. Medicinal plants are capable of synthesizing thousands of diverse bioactive constituents. These compounds may elicit a diverse range of different effects on humans and animals. Chemical compounds of herbal origin and those of the conventional drugs accomplish their effects on the human body through similar processes and mechanisms of action. Medicinal plants are a promising source for the development of novel therapeutics for various diseases [1], including cancer [2, 3]. In recent years, there has been a growing interest in natural phenolic compounds and their presumed roles in the prevention and treatment of various degenerative diseases, such as cancer and cardiovascular disease $[4,5]$.

Tanacetum vulgare $\mathrm{L}$. (common tansy) is a perennial, herbaceous plant species (Asteraceae family) native to temperate Europe and Asia but invasive to other parts of the world. Tansy is widely used in traditional medicine in different parts of Eastern Europe. Extracts of the herb show antioxidant, anti-inflammatory, antiulcerogenic, antiviral, antimicrobial and anticancer activities [6]. Overdosing with teas containing tansy is considered

\footnotetext{
* To whom all correspondence should be sent:

E-mail: vasileva_anelia@abv.bg

to be dangerous due to the presence of the toxic monoterpene, $\alpha$-thujone in the plant. Tansy is also an abortifacient herb. Nevertheless, there appears to be a wide margin of safety for the therapeutic use of the aqueous extract of herb leaves. Previous studies on the crude extract from $T$. vulgare have shown antitumor activity against MCF-7 breast cancer cell line [7]. The chloroform fraction of the crude extract of the herb possesses a significantly stronger inhibitory effect on the proliferation of tumor cell lines HeLa, MCF-7 and A2780 compared to the total extract [8]. The main nonvolatile components in $T$. vulgare flower extract are caffeoylquinic and dicaffeoylquinic acids [9, 10], flavonoids and their O-glycosylated (Oglucosides and O-glucuronides) derivatives [9 11]. The antitumor potential demonstrated by the chloroform fraction of T. vulgare [8] suggests that future in-depth studies are required to gain better understanding of the antitumor properties exhibited by various extracts and fractions of the herb, as well as for the identification of the active ingredients contained within them. The aim of the present work was to determine the main components in different extracts and fractions from the flowers of $T$. vulgare and to evaluate their effects on the viability of various tumor cell lines as compared to a control non-tumorogenic cell line.

\section{EXPERIMENTAL}

\section{Chemicals and reagents}

Acetonitrile of mass spectrometry grade was purchased from Merck (Germany). Ethyl acetate, 
diethyl ether, diisopropyl ether and hexane were from Fisher Chemical (UK); formic acid, 98\%, was from Fluka (Germany). High-purity water was obtained using a Purelab UHQ II system from ELGA (Netherland). All reagents were of the highest purity available. The flowers of $T$. vulgare and the dried powdered crude extract of the herb were kindly provided by Vemo 99 Ltd (Sofia, Bulgaria).

\section{Preparation of the ethyl acetate fraction from the crude extract (EACE)}

Twenty $\mathrm{mL}$ of water were added to $5 \mathrm{~g}$ of the powdered crude tansy extract while stirring. $6 \mathrm{~N}$ $\mathrm{HCl}$ was then added in a dropwise manner until a $\mathrm{pH} 3.0$ was achieved. Ethyl acetate $(15 \mathrm{~mL})$ was applied to the aqueous phase while stirring. The organic phase was separated and the aqueous phase was extracted with $10 \mathrm{~mL}$ of ethyl acetate. The combined organic phases were filtered, washed with brine and dried using $\mathrm{Na}_{2} \mathrm{SO}_{4}$. Ethyl acetate was removed under vacuum and a small amount of diisopropyl ether was added. The formed dark yellow solid residue was filtered off and dried.

\section{Preparation of dicyclohexylammonium salts fraction (DCHAS)}

Solid dicyclohexylammonium salts were obtained from the ethyl acetate extract, as follows: The volume of the ethyl acetate extract was reduced to $1 / 4$ and dicyclohexylamine was added dropwise. The obtained precipitate was filtered, washed with diisopropyl ether and dried.

\section{Isolation of solid substance from diethyl ether/hexane (DEHS)}

The filtrate obtained after removal of the dicyclohexylammonium salts was concentrated in vacuo giving a thick oily residue. Diethyl ether was added to the residue, followed by hexane, resulting in a dark yellow precipitate.

\section{Preparation of ethyl acetate extract from Flores Tanaceti (EAFT)}

Sixteen $\mathrm{mL}$ of water and $48 \mathrm{~mL}$ of ethyl acetate were added to $4 \mathrm{~g}$ of Flores Tanaceti while stirring. Then, $6 \mathrm{~N} \mathrm{HCl}$ was added dropwise until the aqueous phase reached a $\mathrm{pH} 3.0$ and the mixture was stirred for an additional hour. Following filtration, the organic phase was separated and processed as above. Finally, diisopropyl ether was added and the obtained precipitate was filtered and dried.

\section{LC-HRMS analysis}

Analysis was carried out using Q Exactive hybrid quadrupole-Orbitrap mass spectrometer
(Thermo Scientific Co, USA) equipped with TurboFlow ${ }^{\circledR}$ LC system, heated electrospray model HESI II on IonMax ${ }^{\circledR}$ (Thermo Scientific Co, USA).

The chromatographic separation of analytes was carried out by Hypersil Gold column $(100 \mathrm{~mm} \times$ $2.1 \mathrm{~mm}$ i.d., $1.9 \mu \mathrm{m}$ ) using the following mobile phases: A: $0.1 \%$ formic acid in water and B: $0.1 \%$ formic acid in acetonitrile at a flow rate of 300 $\mu \mathrm{L} /$ min and gradient: $0 \% \mathrm{~B}$ for $1 \mathrm{~min}, 30-90 \% \mathrm{~B}$ for $30 \mathrm{~min}, 90 \% \mathrm{~B}$ for $5 \mathrm{~min}, 90-0 \% \mathrm{~B}$ for $2 \mathrm{~min}$ and $0 \% \mathrm{~B}$ for $2 \mathrm{~min}$. Injection volume was $10.0 \mu \mathrm{L}$.

Full-scan spectra over the $\mathrm{m} / \mathrm{z}$ range $80-1200$ were acquired in negative ion mode at resolution settings of 70 000. All MS parameters were optimized for sensitivity to the target analytes using the instrument control software program. Q Exactive parameters were: spray voltage $4.0 \mathrm{kV}$, Sheath gas flow rate 32, Auxiliary gas flow rate 10, Spare gas flow rate 3, Capillary temperature 320 ${ }^{\circ} \mathrm{C}$, Probe heater temperature $300^{\circ} \mathrm{C}$ and S-lens RF level 50. All Ion Fragmentation (AIF) mode of operation of mass analyzer was used for extracts compound identification. Optimized values of the collision energy were HCD $25 \%$. Data acquisition and processing were carried out with Xcalibur 2.4® software package (Thermo Scientific Co, USA). Calculations for theoretical $\mathrm{m} / \mathrm{z}$ values were made by Mass Frontier 5.1 Software program (Thermo Scientific Co, USA). Extracts of tansy ( $3 \mathrm{mg}$ ) were dissolved in $1 \mathrm{~mL}$ of $0.1 \%$ formic acid buffer by ultrasound-assisted extraction for $15 \mathrm{~min}$ and $10 \mu \mathrm{L}$ were injected for LC-HRMS analyses.

\section{Cell lines}

In our in vitro experiments, we used several human cancer cell lines as models of common oncological diseases: invasive ductal adenocarcinoma of the breast (MCF-7), triple negative breast adenocarcinoma (MDA-MB-231), non-small cell lung carcinoma (H1299), alveolar non-small cell adenocarcinoma (A549), cervical cancer cell line (HeLa), hepatocellular carcinoma (HepG2), colon carcinoma (HT-29) and prostate carcinoma cell line (PC3). As a model of normal tissue we used the non-tumorigenic epithelial breast cell line (MCF-10A).

\section{In vitro antitumor activity}

The antitumor activity testing was performed on cell cultures from several human cancer cell lines using the standard MTT-dye reduction assay, described by Mosmann [12]. The cell cultures were routinely grown as monolayers in $75 \mathrm{~cm}^{2}$ tissue culture flasks (Orange Scientific), in Dulbecco's Modified Eagle's Medium - high glucose 
A. M. Vasileva et al.: In vitro study on the antitumor activity of Tanacetum vulgare L. extracts

(DMEM), supplemented with $10 \%$ fetal calf serum and antibiotics. Cultures were maintained at 37.5 ${ }^{\circ} \mathrm{C}, 5 \% \mathrm{CO}_{2}$, in a humidified atmosphere. Cells were plated at a density of $1 \times 10^{3}$ cells per well in 96-well flat-bottomed microplates and allowed to adhere for $24 \mathrm{~h}$ before treatment with the test compounds, dissolved in ethanol, and further diluted in culture medium to the final concentrations. A concentration range from 10 to $500 \mu \mathrm{g} / \mathrm{mL}$ was tested over an incubation period of $72 \mathrm{~h}$. All experiments were performed in triplicate. The MTT-formazan absorption was measured using a microplate reader (TECAN, Sunrise TM, Groedig/Salzburg, Austria) at $580 \mathrm{~nm}$. Antiproliferative activities were expressed as $\mathrm{IC}_{50}$ values (concentrations required for $50 \%$ inhibition of cell growth), calculated using non-linear regression analysis (GraphPad Prizm4 Software).
There was a good reproducibility between replicates with standard deviation below $\pm 10 \%$. The statistical analysis involved One-way ANOVA followed by Bonferroni's post hoc test. $\mathrm{p}<0.05$ was accepted as the lowest level of statistical significance.

\section{RESULTS AND DISCUSSION}

\section{Characterization of compounds in the crude extract}

We determined the major nonvolatile compounds in the extract of $T$. vulgare, provided by Vemo 99 Ltd., by LC-HRMS method in negative ionization mode. Compounds were identified via $\mathrm{MS}^{2}$ analyses and compared with literature data as is discussed below and summarized in Table 1. The total ion chromatogram (TIC) of the crude extract is presented in Fig. 1.

Table 1. Identification of phytochemical compounds in $T$. vulgare crude extract by LC-HRMS in negative mode

\begin{tabular}{|c|c|c|c|c|}
\hline $\begin{array}{l}\text { Peak } \\
\text { № }\end{array}$ & $\begin{array}{l}{[\mathrm{M}-\mathrm{H}]^{-} \mathrm{m} / \mathrm{z}} \\
\text { Delta }(\mathrm{ppm})\end{array}$ & $\begin{array}{l}\text { Molecular } \\
\text { formula }\end{array}$ & $\mathrm{MS}^{2}$ data $\mathrm{m} / \mathrm{z},($ R.I., $\%)$ & $\begin{array}{l}\text { Proposed } \\
\text { compound }^{\mathrm{a}}\end{array}$ \\
\hline & & & Hydroxycinnamoylquinic acids & \\
\hline 1 & $\begin{array}{l}353.0873 \\
(0.79)\end{array}$ & $\mathrm{C}_{16} \mathrm{H}_{18} \mathrm{O}_{9}$ & $\begin{array}{c}191.0548(73), 179.0336(18), \\
135.0435(100), 85.0277(12)\end{array}$ & $\begin{array}{l}\text { 3-caffeoylquinic acid } \\
\qquad[9,10]\end{array}$ \\
\hline 2 & $\begin{array}{l}353.0871 \\
(1.01)\end{array}$ & $\mathrm{C}_{16} \mathrm{H}_{18} \mathrm{O}_{9}$ & $191.0548(100), 173.0441(8)$ & $\begin{array}{c}\text { 5-caffeoylquinic acid } \\
\qquad[9,10]\end{array}$ \\
\hline 3 & $\begin{array}{l}515.1185 \\
\quad(0.25)\end{array}$ & $\mathrm{C}_{25} \mathrm{H}_{24} \mathrm{O}_{12}$ & $\begin{array}{c}353.0873(9), 335.0770(7), 191.0548 \\
(50), 179.0336(91), 173.0442(100), \\
161.0229(27), 155.0334(11) \\
135.0435(34)\end{array}$ & $\begin{array}{c}\text { 3,4-dicaffeoylquinic acid } \\
{[9,10]}\end{array}$ \\
\hline 4 & $\begin{array}{l}515.1186 \\
\quad(0.36)\end{array}$ & $\mathrm{C}_{25} \mathrm{H}_{24} \mathrm{O}_{12}$ & $\begin{array}{c}353.0872(33), 191.0548(100), \\
179.0336(66), 173.0442(4), \\
161.0229(5), 135.0435(23)\end{array}$ & $\begin{array}{c}\text { 3,5-dicaffeoylquinic acid } \\
{[9,10]}\end{array}$ \\
\hline 5 & $\begin{array}{c}515.1186 \\
(0.48)\end{array}$ & $\mathrm{C}_{25} \mathrm{H}_{24} \mathrm{O}_{12}$ & $\begin{array}{c}191.0548(100), 179.0336(12) \\
161.0229(8), 135.0435(6)\end{array}$ & $\begin{array}{c}\text { 1,5-dicaffeoylquinic acid } \\
{[13,14]}\end{array}$ \\
\hline 6 & $\begin{array}{l}515.1186 \\
(0.36)\end{array}$ & $\mathrm{C}_{25} \mathrm{H}_{24} \mathrm{O}_{12}$ & $\begin{array}{c}353.0874(46), 191.0549(34), \\
179.0337(73), 173.0442(100), \\
161.0230(5), 135.0436(22)\end{array}$ & $\begin{array}{c}\text { 4,5-dicaffeoylquinic acid } \\
{[9,10]}\end{array}$ \\
\hline 7 & $\begin{array}{l}285.0402 \\
(0.89)\end{array}$ & $\mathrm{C}_{15} \mathrm{H}_{10} \mathrm{O}_{6}$ & $\begin{array}{c}\text { Flavonoids } \\
151.0021(10), 133.0279(100), \\
107.0122(11)\end{array}$ & Luteolin [9 - 11] \\
\hline 8 & $\begin{array}{l}345.0613 \\
(2.27)\end{array}$ & $\mathrm{C}_{17} \mathrm{H}_{14} \mathrm{O}_{8}$ & $\begin{array}{l}330.0379(22), 315.0144(72), \\
287.0194(100), 149.0229(50)\end{array}$ & $\begin{array}{l}\text { Quercetagetin dimethyl } \\
\text { ether }[9,10]\end{array}$ \\
\hline 9 & $\begin{array}{l}329.0663 \\
(0.76)\end{array}$ & $\mathrm{C}_{17} \mathrm{H}_{14} \mathrm{O}_{7}$ & $\begin{array}{c}299.0189(22), 271.0244(100), \\
243.0289(7), 227.0340(6), 199.0389 \\
(10)\end{array}$ & Eupalitin $[10,11]$ \\
\hline 10 & $\begin{array}{l}463.0877 \\
(0.60)\end{array}$ & $\mathrm{C}_{21} \mathrm{H}_{20} \mathrm{O}_{12}$ & $\begin{array}{l}\text { Flavonoid-O-glucuronides } \\
287.0556(13), 151.0021(100), \\
135.0435(40), 113.0228(9)\end{array}$ & $\begin{array}{l}\text { Eriodictyol-O- } \\
\text { glucoronide [11] }\end{array}$ \\
\hline 11 & $\begin{array}{l}477.0662 \\
\quad(0.25)\end{array}$ & $\mathrm{C}_{21} \mathrm{H}_{18} \mathrm{O}_{13}$ & $\begin{array}{c}301.0347(100), 178.9973(5), \\
151.0021(15)\end{array}$ & $\begin{array}{l}\text { Quercetin-3-O- } \\
\text { glucuronide [15] }\end{array}$ \\
\hline 12 & $\begin{array}{l}461.0720 \\
\quad(0.21)\end{array}$ & $\mathrm{C}_{21} \mathrm{H}_{18} \mathrm{O}_{12}$ & $285.0399(100)$ & $\begin{array}{c}\text { Luteolin-7-O-glucuronide } \\
{[9-11]}\end{array}$ \\
\hline
\end{tabular}




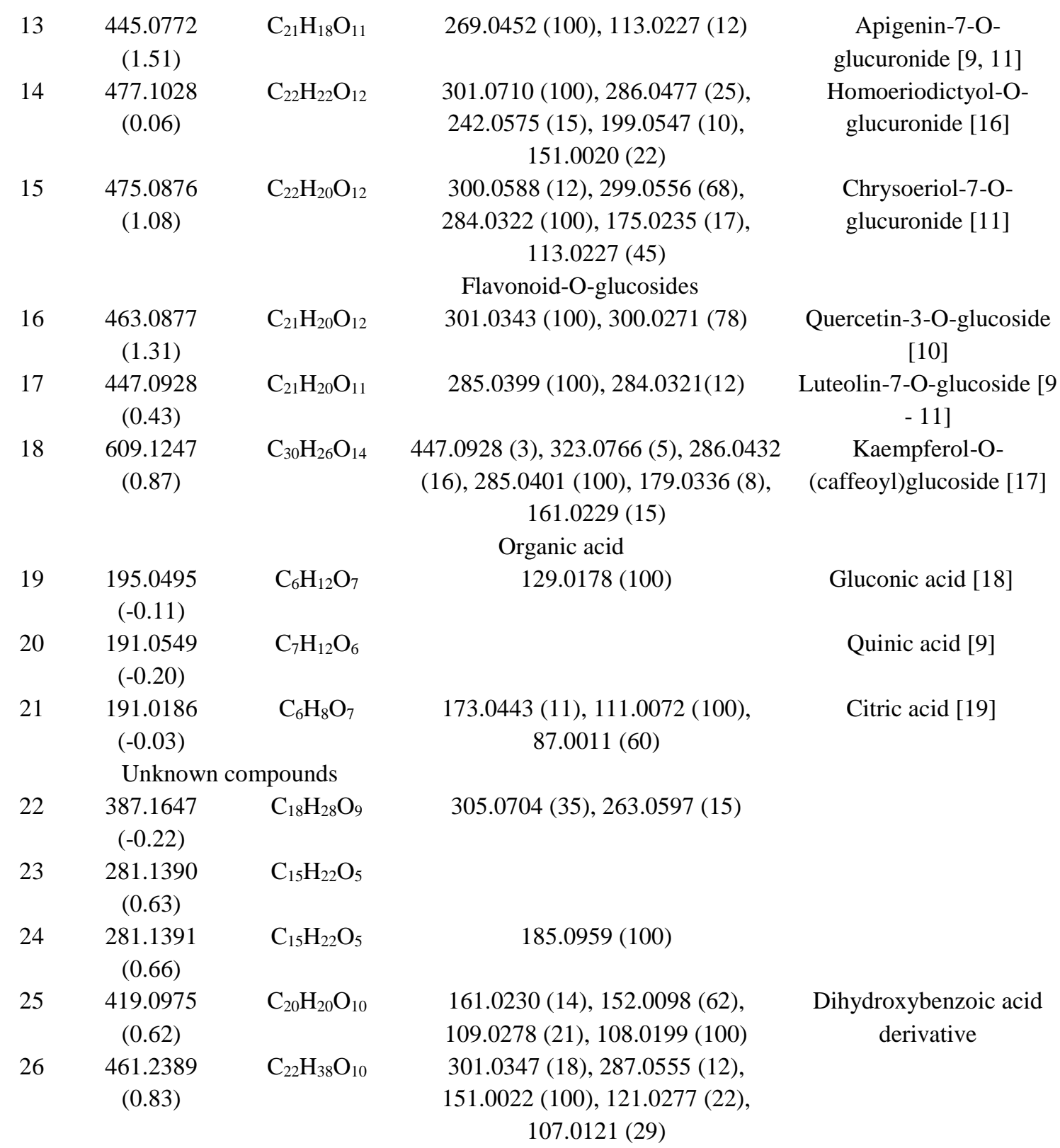

${ }^{a}$ Consistent with the literature on the presence of these compounds in the tansy or based on the comparison of $\mathrm{m} / \mathrm{z}$ values from the $\mathrm{MS}^{2}$ spectra with the literature data.

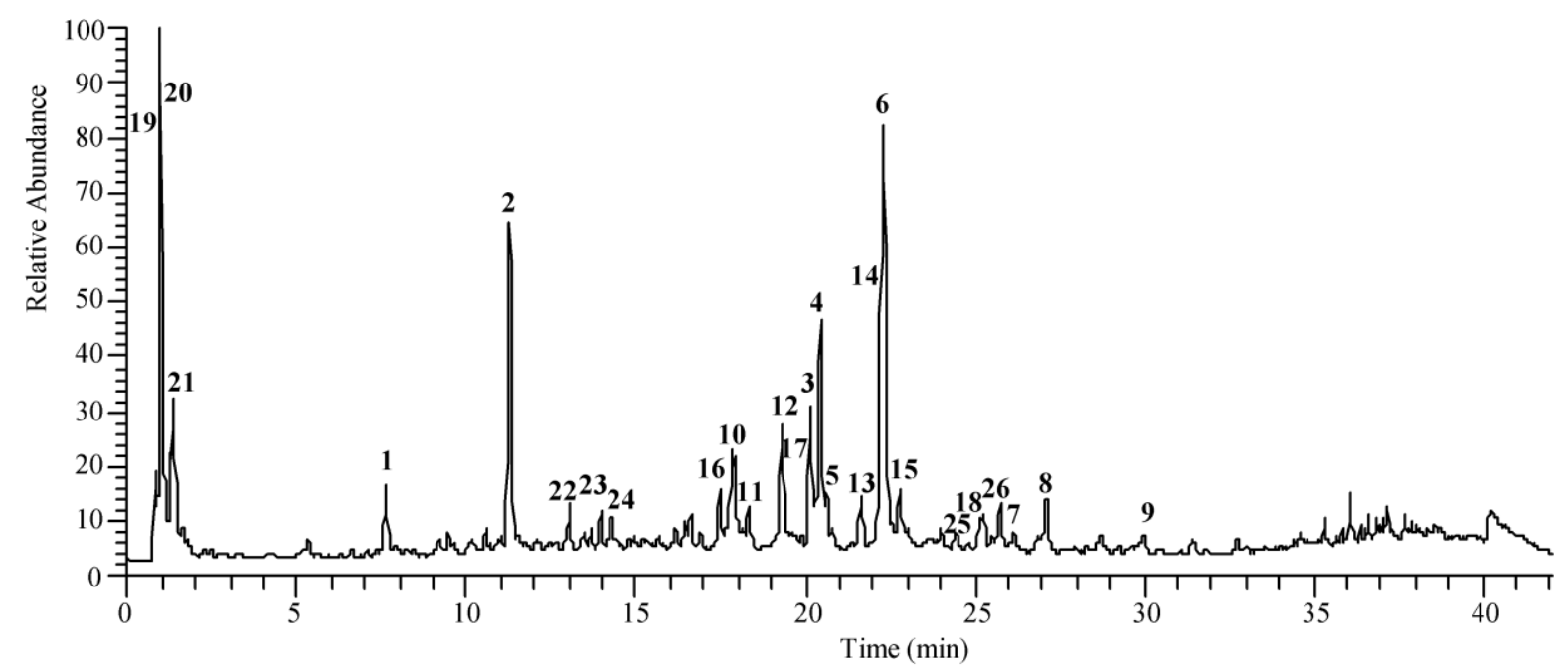

Fig. 1. Total ion chromatogram (TIC) of T. vulgare crude extract in negative ion mode. The numbering of the compounds corresponds to Table 1. 
A. M. Vasileva et al.: In vitro study on the antitumor activity of Tanacetum vulgare L. extracts

Compounds 1 and 2 showed a $[\mathrm{M}-\mathrm{H}]^{-}$ion at $\mathrm{m} / \mathrm{z}$ 353.08 in negative-ion mode, enabling the identification of the two isomers of caffeoylquinic acid (CQA). The primary degradation pathways of isomeric CQAs generate fragment ions with $\mathrm{m} / \mathrm{z}$ 191 corresponding to [quinic acid-H]; $\mathrm{m} / \mathrm{z} 179$ corresponding to [caffeic acid-H],$\quad \mathrm{m} / \mathrm{z} 173$ corresponding to [quinic acid- $\left.\mathrm{H}-\mathrm{H}_{2} \mathrm{O}\right]^{-}$and $\mathrm{m} / \mathrm{z} 135$ corresponding to [caffeic acid- $\left.\mathrm{CO}_{2}\right]^{-}$, which are characteristic and the differences in their intensity could be used to correctly identify the respective CQAs [13, 14]. Thus, compounds 1 and $\mathbf{2}$ were identified as 3-CQA and 5-CQA, respectively. Compounds 3 - 6 gave the $[\mathrm{M}-\mathrm{H}]^{-}$ions at $\mathrm{m} / \mathrm{z}$ 515.12, indicating that they were dicaffeoylquinic acid (diCQA) isomers. The specific product ions mentioned above were observed in the $\mathrm{MS}^{2}$ spectrum, as well as an ion with $\mathrm{m} / \mathrm{z} 353.08$ corresponding to [CQA-H] $]^{-}$A specific ion with $\mathrm{m} / \mathrm{z} 335.08$ was observed in the spectrum of 3,4diCQA (compound 3). The isomers of diCQAs could be distinguished by the intensity of product ions $[13,14]$. A total of twelve flavonoids and their derivatives were characterized in $T$. vulgare, including two aglycone flavonoids (compounds $\mathbf{7}$, 9), one flavonoid dimethyl ether (compound 6), six flavonoid-O-glucuronides (compounds 10 -15) and three flavonoid-O-glucosides (compounds 16 -18). Generally, the flavonoid aglycones in tansy were luteolin, quercetin and apigenin. The sugar type can be easily deduced from the difference between the mass of parent ions and the mass of aglycone fragments. The loss of 162 and $176 \mathrm{Da}$ corresponded to hexoside and glycuronide moieties, respectively. Identification of the aglycone part of flavonoid-O-glycosides and the structures of flavonoid-O-glycosides could be determined by performing analyses of the $\mathrm{MS}^{2}$ spectrum and comparison with the corresponding spectra in a related reference (see Table 1). The presence of three organic acids (gluconic, quinic and citric acid) and five unknown compounds is detected in the crude extract of $T$. vulgare.

\section{Characterization of compounds in the ethyl acetate fraction}

The extractability of the phenolic compounds is known to be influenced by the polarity of the solvent used. Ethyl acetate was proposed by Ignat et al. [20] as the organic solvent for extraction of polyphenols. Powder of the crude tansy extract was treated with a two-phase solvent system consisting of ethyl acetate and water. Aqueous phase was acidified to $\mathrm{pH} 3$, resulting in precipitation of acidic substances such as isomeric caffeoylquinic, dicaffeoylquinic acids and flavonoid-O- glucuronides, which led to an increase of the partition coefficients of these compounds. The LCHRMS analysis of the ethyl acetate fraction showed that relatively more hydrophobic components were extracted in the organic phase. Hydrophilic components such as gluconic, quinic and citric acid were not detected in this fraction.

\section{Characterization of dicyclohexylammonium salts}

After reduction of the ethyl acetate fraction volume, a dicyclohexylamine was added. A yellow precipitate was formed as a result of the reaction. The analysis of the dried solid substance by LCHRMS indicated the presence of 3- and 5-CQA, 3,4-, 3,5-, 4,5- and 1,5-diCQA, flavonoid-Oglucuronides and luteolin. No flavonoid-Oglucosides were detected. This is a simple method for separation of acidic from other substances, in particular flavonoid-O-glucuronides from other flavonoid-O-hexosides.

\section{Characterization of the solid from diethyl ether/hexane}

Analysis of the obtained dark yellow solid substance after precipitation with diethyl ether/hexane revealed the presence of quercetagetin dimethyl ether, eupalitin, an unknown compound with $\mathrm{m} / \mathrm{z}$ 457.21, residual quantity of 5-CQA, luteolin, homoeriodictyol-O-glucuronide and other unidentified compounds.

\section{Characterization of compounds in the ethyl acetate extract}

Flores Tanaceti were treated with a two-phase solvent system consisting of ethyl acetate and water ( $\mathrm{pH}$ of aqueous phase was 3). Water induced swelling of the plant particles and increased the porosity of the cell wall and thus facilitated the diffusion of extracted substances into the organic solvent. The use of ethyl acetate resulted in a significant improvement of the extraction of compounds and resulted in considerable reduction of the amount of used solvent. Through LC-HRMS we found that hydrophobic components were extracted more efficiently with ethyl acetate than by the traditionally used approach with alcohol-water mixtures. Hydrophilic components such as gluconic, quinic and citric acid were not detected in this extract. The above extraction method has many advantages over the traditionally used approach using alcohol-water mixtures. Separation of hydrophilic and relatively hydrophobic components is accomplished in a single step and the organic phase was practically free of tannins. 


\section{Antitumor activity}

Tansy extracts and fractions were tested in vitro on a panel of 9 cell lines - 1 control and 8 tumor lines. Antitumor activity was determined after $72 \mathrm{~h}$ of incubation with the respective substances at concentrations from 10 to $5000 \mu \mathrm{g} / \mathrm{mL}$. The observed antiproliferative effect showed a doseresponse sigmoidal curve (data not shown). Using these curves we calculated the $\mathrm{IC}_{50} \pm \mathrm{SD}$ values (Table 2). For the control MCF-10A cell line, the lowest toxicities were observed with CETV, EACE and EAFT $\left(\mathrm{IC}_{50}=875 \pm 21.9 \mu \mathrm{g} / \mathrm{mL}, 438 \pm 16.8\right.$ $\mu \mathrm{g} / \mathrm{mL}$ and $174.1 \pm 8.4 \mu \mathrm{g} / \mathrm{mL}$, respectively). In tumor cells, the lowest $\mathrm{IC}_{50}$ was observed with the DCHAS, DEHS, EAFT $\left(\mathrm{IC}_{50}=18 \pm 3.4 \mu \mathrm{g} / \mathrm{mL}\right.$ for $\mathrm{H} 1299, \mathrm{IC}_{50}=29 \pm 2.1 \mu \mathrm{g} / \mathrm{mL}$ for MDA-MB-231 $\mu \mathrm{g} / \mathrm{mL}$ and $\mathrm{IC}_{50}=22.8 \pm 1 \mu \mathrm{g} / \mathrm{mL}$ for MCF-7 respectively). The highest selectivity index $\left(\mathrm{IC}_{50}\right.$ of MCF-10A $/ \mathrm{IC}_{50}$ of the tumor cell line) was observed with EACE and EAFT (Fig. 2).

The highest selectivity index was found for MCF-7 with EAFT (7.6) and for the same cell line with EACE (4.71). Analysis of the obtained results revealed that the EAFT from $T$. vulgare exhibited the highest potential as an antitumor agent, followed by the EACE. From the above results becomes evident that ethyl acetate extracts contain substances bearing the highest selective activity towards tumor cells. On the other hand, those substances are obviously concentrated in tansy flowers.

Table 2. $\mathrm{IC}_{50}$ values obtained by MTT assay for extracts and fractions of $T$. vulgare after $72 \mathrm{~h}$ of treatment. Data are expressed as mean \pm SD values of three independent experiments, each made in triplicate.

\begin{tabular}{cccccc}
\hline \multirow{2}{*}{ Cell lines } & \multicolumn{5}{c}{${\text { Mean } \mathrm{IC}_{50} \pm \mathrm{SD}(\mu \mathrm{g} / \mathrm{mL})}$} \\
\cline { 2 - 6 } & CETV $^{\mathrm{a}}$ & EACE $^{\mathrm{b}}$ & DCHAS $^{\mathrm{c}}$ & DEHS $^{\mathrm{d}}$ & EAFT $^{\mathrm{e}}$ \\
\hline MCF-10 & $875 \pm 21.9$ & $438 \pm 16.8$ & $53 \pm 6.4$ & $36 \pm 1.9$ & $174.1 \pm 8.4$ \\
MCF-7 & $380 \pm 13.6$ & $93 \pm 5.7$ & $294 \pm 19.3$ & $91 \pm 7$ & $22.84 \pm 1.0$ \\
MDA-MB-231 & $943 \pm 12.8$ & $443 \pm 21.9$ & $47 \pm 11$ & $29 \pm 2.1$ & $60.6 \pm 0.7$ \\
H1299 & $410 \pm 1.6$ & $121 \pm 1.7$ & $18 \pm 3.4$ & $40 \pm 5.2$ & $60.5 \pm 0.6$ \\
A549 & $391 \pm 5.2$ & $117 \pm 5.7$ & $199 \pm 15.9$ & $91 \pm 8.1$ & $35.6 \pm 1.8$ \\
HeLa & $483.9 \pm 26.4$ & $227.1 \pm 2.2$ & $473.6 \pm 5.1$ & $203.7 \pm 10.4$ & $57.46 \pm 2.0$ \\
HepG2 & $453.7 \pm 7.4$ & $177.9 \pm 18.9$ & $297.7 \pm 12.4$ & $160.3 \pm 6.6$ & $73.5 \pm 2.4$ \\
HT-29 & $329.7 \pm 16.2$ & $128.4 \pm 6.5$ & $153 \pm 9.8$ & $193.3 \pm 15.1$ & $42.5 \pm 3.1$ \\
PC3 & $231.9 \pm 9.6$ & $101.2 \pm 8.0$ & $195 \pm 5.0$ & $124.6 \pm 7.8$ & $37.4 \pm 1.2$ \\
\hline
\end{tabular}

${ }^{\mathrm{a}} \mathrm{CETV}$ - crude extract of T. vulgare; ${ }^{\mathrm{b}} \mathrm{EACE}$ - ethyl acetate fraction from the crude extract of T. vulgare; ${ }^{\mathrm{c} D C H A S}-$ dicyclohexylammonium salts fraction; ${ }^{\mathrm{d} D E H S}$ - solid substance from diethyl ether/hexane separation; ${ }^{\mathrm{e}} \mathrm{EAFT}-\mathrm{ethyl}$ acetate extract from Flores Tanaceti.

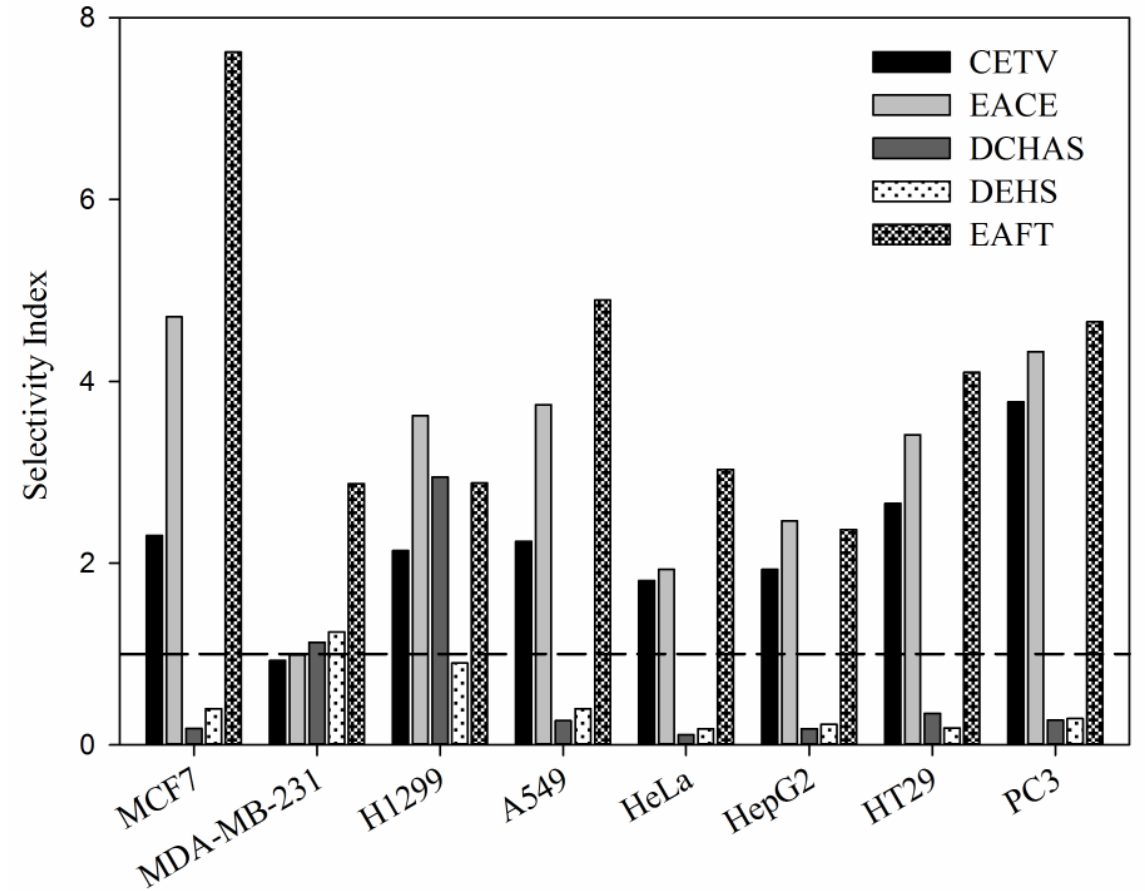

Fig. 2. The selectivity index (SI) of tumor cell lines obtained using $\mathrm{IC}_{50}$ values. SI represents $\mathrm{IC}_{50}$ for $\mathrm{MCF}-10 \mathrm{cell}$ line $/ \mathrm{IC}_{50}$ for cancerous cell lines, after $72 \mathrm{~h}$ of treatment. 
A. M. Vasileva et al.: In vitro study on the antitumor activity of Tanacetum vulgare L. extracts

According to a previous study [8] the main antitumor activity of $T$. vulgare flowers in MCF-7 cell line was demonstrated by the chloroform fraction. In our study we used an ethyl acetate extract from tansy flowers which contained a different set of compounds. Our results showed that EAFT had the highest antitumor activity and selectivity towards MCF-7 and other tumor cell lines in comparison to the control MCF-10A cell line (Table 2 and Fig. 2). Further study of individual compounds in this ethyl acetate extract should be conducted to identify the main active substance(s) exhibiting antitumor properties.

Acknowledgement: This work is financially supported by the Medical University-Sofia, Scientific Fund, Grant № D-129/2018 and the National Science Fund of the Bulgarian Ministry of Education and Science, Grant № T02/25 2014.

\section{REFERENCES}

1. M. R Goyal, A. O Ayeleso (eds.), Bioactive Compounds of Medicinal Plants: Properties and Potential for Human Health, CRC Press, 2018.

2. G. M. Cragg, J. M Pezzuto, Med Princ Pract., 25 (Suppl. 2), 41 (2016).

3. R. Arpita, A. Shruti, B. Navneeta, J. Plant Sci. Agric. Res., 2(1), 008 (2017).

4. K. Pandey, S. Rizvi, Oxid. Med. Cell Longev. NovDec, 2 (5), 270 (2009).

5. C. G. Fraga (ed.), Plant phenolics and human health: biochemistry, nutrition and pharmacology, vol. 1, John Wiley \& Sons, 2009.
6. T. K. Lim (ed.), Edible medicinal and non-medicinal plants. Vol. 7, Flowers, Springer, 2014, p. 501.

7. Z. Gospodinova, G. Antov, S. Angelova, M. Krasteva, Int. J. Pharma. Sci., 4 (2), 468 (2014).

8. Z. Gospodinova, N. Bózsity, I. Ocsovszki, O. Orbán-Gyapai, M. Krasteva, I. Zupkó, Int. J. Pharma. Sci., 5 (2), 986 (2015).

9. R. Baranauskienè, R. Kazernavičiūtè, M. Pukalskienè, R. Maždžierienė, P. R. Venskutonis, Ind. Crops Prod., 60, 113 (2014).

10. N. Devrnja, B. Anđelković, S. Aranđelović, S. Radulović, M. Soković, D. Krstić-Milošević, M. Ristić, D. Ćalić, S. Afr. J. Bo., 111, 212 (2017).

11. A. Uehara, S. Akiyama, T. Iwashina, Nat. Prod. Commun., 10 (3), 403 (2015).

12. T. Mosmann, J. Immunol. Methods, 65 (1-2), 55 (1983).

13. M. N. Clifford, S. Knight, N. Kuhnert, J. Agric. Food Chem., 53 (10), 3821 (2005).

14. J. Y. Zhang, Q. Zhang, N. Li, Z.J. Wang, J.Q. Lu, Y.J. Qiao, Talanta, 104, 1 (2013).

15. M. Kajdžanoska, V. Gjamovski, S. Stefova, Maced. J. Chem. Chem. Eng., 29, 181 (2010).

16. J. Kang, W.E. Price, J. Ashton, L.C. Tapsell, S. Johnson, Food Chem., 211, 215 (2016).

17. I. Parejo, O. Jáuregui, F. Viladomat, J. Bastida, C. Codina, Rapid Commun. Mass Spectrom., 18 (23), 2801 (2004).

18. S. Li, Z. Lin, H. Jiang, L. Tong, H. Wang, S. Chen, J. Chromatogr. Sci., 54 (7), 1225 (2016).

19. E. J. Llorent-Martínez, G. Zengin, ML. Fernándezde Córdova, O. Bender, A. Atalay, R. Ceylan, A. Mollica, A. Mocan, S. Uysal, G.O. Guler, A. Aktumsek, Front Pharmacol., 8, 83 (2017).

20. I. Ignat, I. Volf, V.I. Popa, Food Chem., 126 (4), 1821 (2011). 